University of Louisville

ThinkIR: The University of Louisville's Institutional Repository

$12-2014$

\title{
Portrayals of mental illness and physical disability in 21st century children's animation.
}

Amy Sue Marie Miller

University of Louisville

Follow this and additional works at: https://ir.library.louisville.edu/honors

Part of the Communication Commons

\section{Recommended Citation}

Miller, Amy Sue Marie, "Portrayals of mental illness and physical disability in 21 st century children's animation." (2014). College of Arts \& Sciences Senior Honors Theses. Paper 40.

http://doi.org/10.18297/honors/40

This Senior Honors Thesis is brought to you for free and open access by the College of Arts \& Sciences at ThinkIR: The University of Louisville's Institutional Repository. It has been accepted for inclusion in College of Arts \& Sciences Senior Honors Theses by an authorized administrator of ThinkIR: The University of Louisville's Institutional Repository. This title appears here courtesy of the author, who has retained all other copyrights. For more information, please contact thinkir@louisville.edu. 
Portrayals of Mental Illness and Physical Disability in $21^{\text {st }}$ Century Children's Animation

Portrayals of Mental Illness and Physical Disability in $21^{\text {st }}$ Century Children's Animation by

Amy Sue Marie Miller

Submitted in partial fulfillment of the requirements

for Graduation summa cum laude

University of Louisville

December, 2014 
Portrayals of Mental Illness and Physical Disability in $21^{\text {st }}$ Century Children's Animation

\begin{abstract}
The objective of this study was to evaluate the presence of mental and physical disability in children's animation, and to understand image of mental or physical disability the animation portrayed. Three animated movies and one 61 episode animated series were coded for verbal references to mental illness and physical disability. Visual images and thematic elements portraying disability were also examined. All of the animations contained verbal as well as visual references to disability. Verbal references appeared with an average of 13.2 references per hour of animation. The connotations of these references often went against negative stereotypes of disability. These findings have implications for the viewers of these animations in terms of possible learned attitudes and stereotypes toward disability that these references may facilitate over time.
\end{abstract}


Portrayals of Mental Illness and Physical Disability in $21^{\text {st }}$ Century Children’s Animation

\section{Background}

\section{Why should we care about media?}

The total number of television households in American in 2013 was 115 billion (Neilson, 2013). Nearly 250 million people listen to radio on a weekly basis (Nielson, 2014). Media companies spend close to $\$ 70$ billion on TV advertising in the U.S. (Neilson, n.d.). In 2014, total movie sales grossed over $\$ 8$ billion in ticket sales alone (Box Office Mojo, 2014). While these figures may not seem surprising in today’s media-saturated society, such lengthy exposure to media has been shown to have lasting effects on the perceptions of the world as a whole.

An audience's perceptions of media may alter the way they associate with the real world world. Bandura (2001) states that “personal agency operates within a broad network of sociostructural influences” (Modes of Human Agency, para. 7), meaning that that the way people perceive themselves and the world they live in stems from the information they are given about it. This information can come from their culture, learned through social interactions, or gleaned from the media that people consume. This information can change the way someone experiences their environment or the people who come in contact with them in that environment. Bandura states, "the nature of these experiences is [...] heavily dependent on the types of social and physical environments people select and construct” (Physicalistic Theory of Human Agency, para. 2).

In regards to media, however, a consumer is not merely selecting their environment; they are having parts of their environment selected for them. While it may tout itself as truth, the reality of the matter is that media is rarely without bias. Consumers have their own "agency", as Bandura pointed out, but so, too, do the creators of media. This “media agency" often manifests as agenda setting or priming. Agenda setting, as McCombs and Shaw (1972) state, "an important 
Portrayals of Mental Illness and Physical Disability in 21 ${ }^{\text {st }}$ Century Children’s Animation part in shaping $[\ldots]$ reality. Readers learn not only about a given issue, but also how much importance to attach to that issue from the amount of information in a news story and its position” (McCombs \& Shaw, 1972). In choosing what parts of news to display and how to display it, editors, radio announcers, newswriters, and broadcasters can highlight or downplay specific parts of their media message to affect the way their consumers receive its importance. By deciding which parts of a story fit their purpose, or "agenda", media providers can change their consumers' perceptions of a story, advertisement, or television program.

In addition to throwing bias onto media, which in turn can bias the opinion of the consumer, media can exaggerate aspects of the real world. These "exaggerations" can lead to unrealistic beliefs about the world outside of media; one of the most common is the fear of crime in the United States. Graber (cited in Weitzer \& Kubrin, 2004) says that 95\% of Americans identify the media as their primary source of information about crime. The media reports on a disproportionate amount of crime compared to other events. Weitzer and Kubrin point out that "this media world, especially television, differs from the real world of crime and may cultivate the perception that the world is a scary place” (p. 497) Media bias may also lead to unrealistic beliefs about groups of people. Marris and Thomham (2000) describe stereotypes in their book as "the representation of people by endowing them with particular recognizable characteristics which are implicitly or explicitly attributed in general to the social group of which they are a member”.

In addition to media bias, the sheer quantity of information that consumers of media are exposed to and the frequencies of certain portrayals are capable of significant influence. Cultivation theory suggests that the world portrayed by television is significantly different than reality, that this distortion alters the perceptions of viewers and, over time, influences their 
Portrayals of Mental Illness and Physical Disability in $21^{\text {st }}$ Century Children’s Animation personal values (Shrum, Burroughs, \& Rindfleisch, 2005). Repeated exposure to themes of materialism would, according to cultivation theory, make heavy consumers of media more likely to place importance upon materialism in their own lives; repeated exposure to derogatory language may cause “a level of desensitization; making such language appear common and acceptable by dulling the normal emotional responses” (Ricke, 2012).

\section{How we learn: The problem with stereotypes}

Heavy consumers of media, including children, are especially susceptible to stereotyping. While stereotypes are not always necessarily negative, they are usually seen as prejudiced (Marris \& Thomham, 2000 p. 198). Dubriel (2006) states in his thesis that "most studies have shown that African Americans are more likely than Caucasians to be portrayed as a criminal suspect” (p. 2) in television. Stice and Shaw (1994) discuss the effect that "thin-ideal” stereotypes have on the eating habits of young women. Studies like these describe a negative effect of stereotyping; consumers of media that include heavy stereotyping are more likely to align their beliefs about the groups depicted in their stereotypic representations. Problems with representation appear across a broad spectrum of gender, sexual orientation, and race. When negative stereotypes exist in popular media, including movies and television, the social groups targeted by those stereotypes are more likely to suffer some sort of repercussion.

Without realistic representations in media, stereotypes become the prevailing image society has of a particular group. When media portrays people with disabilities as "sickly and helpless victims”, it implies that a “disabled person’s life is inferior to [...] an able-bodied person’s life” (Zhang \& Haller, 2013). In addition, physical and mental disabilities have been negatively affected by portrayals of insane or murderous characters in media. "Supercrip” (Quilan \& Bates, 2008) characters who have their disabilities glorified as superpowers, like 
Portrayals of Mental Illness and Physical Disability in $21^{\text {st }}$ Century Children’s Animation Marvel’s blind Daredevil (Marvel, 2014), “vengeful cripples” who act as bitter antagonists to other, able-bodied characters, like Darth Vader from the acclaimed Star Wars series, and “mad”, “loony”, or “insane” mentally ill characters, such as the Joker of the Batman series, all portray images that negatively affect the perception of the disabled in real life. Quilan and Bates described the "supercrip" as a stereotype that could lead to the creation of false expectations and unrealistic goals for the disabled; Laroi and Van der Linden (2009) found that negative depictions of schizophrenia in media could result in a number of negative consequences for people with schizophrenia due to public reaction, "including aggravating their condition and making it even more difficult for them to assimilate into society” (p. 61). In their analysis of eighteen films produced between 1975 and 2004 that included characters who were physically disabled, Black and Pretes (2007) found that "many of the movies portrayed integrated community life, but integrated education and employment opportunities were noticeably lacking” (p. 66). These kinds of perceptions can perpetuate stigmatization, fear and distrust toward those living with mental and physical disabilities, and "tragically [deprive] people of their dignity and [interfere] with their full participation in society (Wahl, 2003, p. viii).

People living with physical disabilities make up about 20 percent of the population in the U.S. (United States Census Bureau, 2012), and one in five adults in the U.S. have a diagnosable mental illness (Preidt, 2014). Yet the appearance of physically disabled characters on TV is only one percent (GLAAD, 2013). Psychological disorders that experience greater media representation are also heavily stereotyped; mentally ill characters are often presented as dangerous or incapable of functioning in normal society, and many are cast as villains. The Joker is not the only character in the Batman franchise that is portrayed as unstable and dangerous (DC Comics, 2014); many of the recurring villains in the series are escapees from Gotham City’s 
Portrayals of Mental Illness and Physical Disability in $21^{\text {st }}$ Century Children’s Animation mental hospital, The Elizabeth Arkham Asylum for the Criminally Insane. Likewise, characters with physical disabilities on television are often oversimplified, flat, or used as an "irredeemable villain” or a sort of “evil avenger” (Hartnett, 2000). The "mad villain” stereotype is the one that is the most persistent in older children's animation. To be “mad” in early Disney movies is to be dangerous, unpredictable, or unreliable. The villains are often described as “mad.” Characters such as "Mad Madame Mim”, the evil witch in The Sword in the Stone, and the "Mad Queen” and "Mad Hatter" in Alice in Wonderland, are threats to the protagonist. These characters act unpredictable and are often cruel or unfair. The entire premise of Alice in Wonderland is the idea that the title character has fallen into a "mad,” topsy-turvy world far removed from her normal life, implied to be a punishment for not being proper and paying attention during her lessons.

Disabled characters appear often as stereotyped or satirized in television for adults. For example Mayor Adam West, a recurring character in Fox’s long-running series Family Guy, is portrayed as eccentric, manic, and a hazard to his own health. Joe Swanson, a paralyzed police officer from the same series, is consistently portrayed throughout the run of the series on the opposite side of the spectrum, possessing “over-aggressive with alcoholic and abusive tendencies” (IMDb, 2009, para. 1). Peter Griffin, one of the main characters in Family Guy, is repeatedly implied to be mentally disabled and is often the cause of conflict in each episode. In episode 56, "Petarded,” Peter Griffin is formally diagnosed with as having a mental disability. He spends much of the episode using his disabled status to get away with breaking societal rules, including walking into the women's restroom and starting fights. At the same time, the community treats Peter as though his "new” status of disability renders him incapable of doing things he once did without trouble, and actually deem him an unfit father as a result. Medjesky 
Portrayals of Mental Illness and Physical Disability in $21^{\text {st }}$ Century Children’s Animation (2008) points out that this scenario "shows how society will view the disabled as childlike, incomplete as an adult human.”

\section{The impact of social cognitive theory and cultivation}

Social cognitive theory emphasizes learning behaviors through social context and observation. It has been applied to many different areas of human functioning, from career choice and organizational behavior, to mental and physical health (Denler, Wolters, \& Benzon, 2014). In the context of media, social cognitive theory can be applied to describe behaviors that consumers of media learn through their media consumption. These behaviors are not always positive. While much useful information can be drawn from today’s media, the repeated portrayal of certain content can also affect the way consumers of media think and behave in response to similar content in the real world. Negative portrayals of race or religion in media are capable of altering the way that race and religion are treated in real life, especially by heavy consumers of media. Lawson and Fouts (2004) suggest that "adult beliefs are rooted in childhood” and that stereotypes are cultivated at an early age. The images cultivated in childhood by animation last long into adulthood, and affect the way that disability is perceived later in life. According to Strasburger, Wilson, and Jordan (2009, p. 18), “children as young as 2 years of age already show preference to certain types of TV programs”. As young viewers, they are susceptible to the early effects of cultivation. Ricke's (2012) study found that language used on television has a socializing effect on children. Ricke found that Family Guy is watched by over 900,000 viewers ages eleven or younger, and because of the commonality and the normalization

of derogatory language used in the programming, “young viewers may have difficulty differentiating between acceptable and unacceptable language on television.” Over 200 million children ages two and older have access to at least one television in the United States alone 
Portrayals of Mental Illness and Physical Disability in $21^{\text {st }}$ Century Children's Animation (Neilson, 2009), in addition to movies, Internet, and other media. Children are especially vulnerable to media portrayals, and prior studies have shown that early and frequent exposure to TV and movies can cultivate a child's attitudes toward a wide range of social groups—and that these early childhood learning experiences carry on into adulthood to affect their perceptions later (Lawson and Fouts, 2004).

In the past, children's animation has used characters that could be considered disabled as villains, comedic relief, or as pitiable caricatures. Over time, children who watch these portrayals of disability may come to accept the "villainous" or "pitiable” stereotype of disability as normal, which may influence their treatment of disabled people in the real world. Similarly, disabled children who watch these stereotyped portrayals may internalize them, which may have repercussions on their self-esteem and sense of self-worth. In this analysis, I examine how elements in twenty-first century animated films and cartoons for children present portrayals of mental illness and physical disability, and whether or not these portrayals align with stereotypical portrayals in earlier children's animation.

\section{Methodology}

This study critically reviewed four 21st century animations for children, in which thematic elements regarding portrayals of mental and physical disability were identified. These animations included: Disney’s Frozen, Disney’s Wreck-It Ralph, Dreamwork’s How to Train Your Dragon 2, and Nickelodeon's Avatar: The Last Airbender. These animations were chosen because they are all critically-acclaimed animations that were released within the last ten years, grossed over one hundred million dollars worldwide during their runs, and have become a part of popular culture. 
Portrayals of Mental Illness and Physical Disability in $21^{\text {st }}$ Century Children’s Animation

Frozen, Wreck-It Ralph, and How to Train Your Dragon 2 were chosen because they were popular feature-length animated movies that have become a part of popular culture, meaning that they were widely merchandised, advertised, and that dialogue, songs, and visual elements from them are often referenced out of the context of their animations. Avatar: The Last Airbender was an animated television series of 61 episodes that each had a run time of about 30 minutes. It was chosen because it ran weekly over the course of four years from 2005 to 2008 and also became a part of popular culture. All of these animations are typical of children's films in that they would be watched repeatedly by their target audience over a period of time. In addition, each of these animations had some sort of obvious portrayal of disability. Avatar: The Last Airbender portrayed a variety of mental and physical illnesses; Frozen had thematic elements that mirrored a mental illness; and How to Train Your Dragon 2 and Wreck-It Ralph both had characters who had obvious physical disabilities. How to Train Your Dragon 2 was chosen over How to Train Your Dragon because the main character gained a physical disability that he did not have in the first movie.

The purposes of this concept analysis were: (1) to evaluate the presence of disability in children's animations and (2) to understand the image of mental or physical disability the animations projected. Data was collected through the analysis of keywords that occurred in the transcripts of these four animated features. Drawing upon the work of Rose, Thornicroft, Pinfold, and Kassam (2007), a list of key words and phrases was generated that referred to disability within the scope of these features (see Appendix A).

Rose, Thornicroft, Pinfold, and Kassam surveyed 634 students around 14 years of age. From this survey they created a list of 250 words that these students associated with mental illness. Most of these words had a negative connotation for these children, and their presence 
Portrayals of Mental Illness and Physical Disability in $21^{\text {st }}$ Century Children’s Animation within these four animations, which are targeted to children younger than 14 years, could support the continued existence of these negative connotations of disability from a young age.

From the original list of 250 words, 179 words were ruled out on the basis of differences in British English dialect with American English dialects, whether or not they were ageappropriate for the target audience of the animations, and whether or not they included medical terminology. However, even after narrowing the 250 word list down to 71 (see Table 1), the majority of these words did not appear within the selected animations. The number of times the remaining 71 key words appeared in each animation was recorded (see Appendix G). In addition, the visual imagery of the animated features was evaluated for any visual depictions of disability that might have been present. These images were categorized according to whether they were overt (direct) references or covert (indirect) references, to disability based upon the context of the use of the word. Finally, the transcripts were then reevaluated for any contextual or thematic elements that may affect the meaning or usage of the keywords or images. 
Portrayals of Mental Illness and Physical Disability in $21^{\text {st }}$ Century Children’s Animation

\section{Findings}

Of the 250 original words in Rose’s study, 71 words were chosen to be used in the analysis of all four animations. Out of those 71 keywords, 48 showed up at least once during the analysis of all four animations, with the remaining 23 words not appearing at all (see table 1). Of the 48 keywords that appeared at least once, 29 words appeared fewer than five times in all four animations (see Table 2 and Table 3).

Table 2: Total number of occurrences of keywords in examined animations (0-29 occurrences)

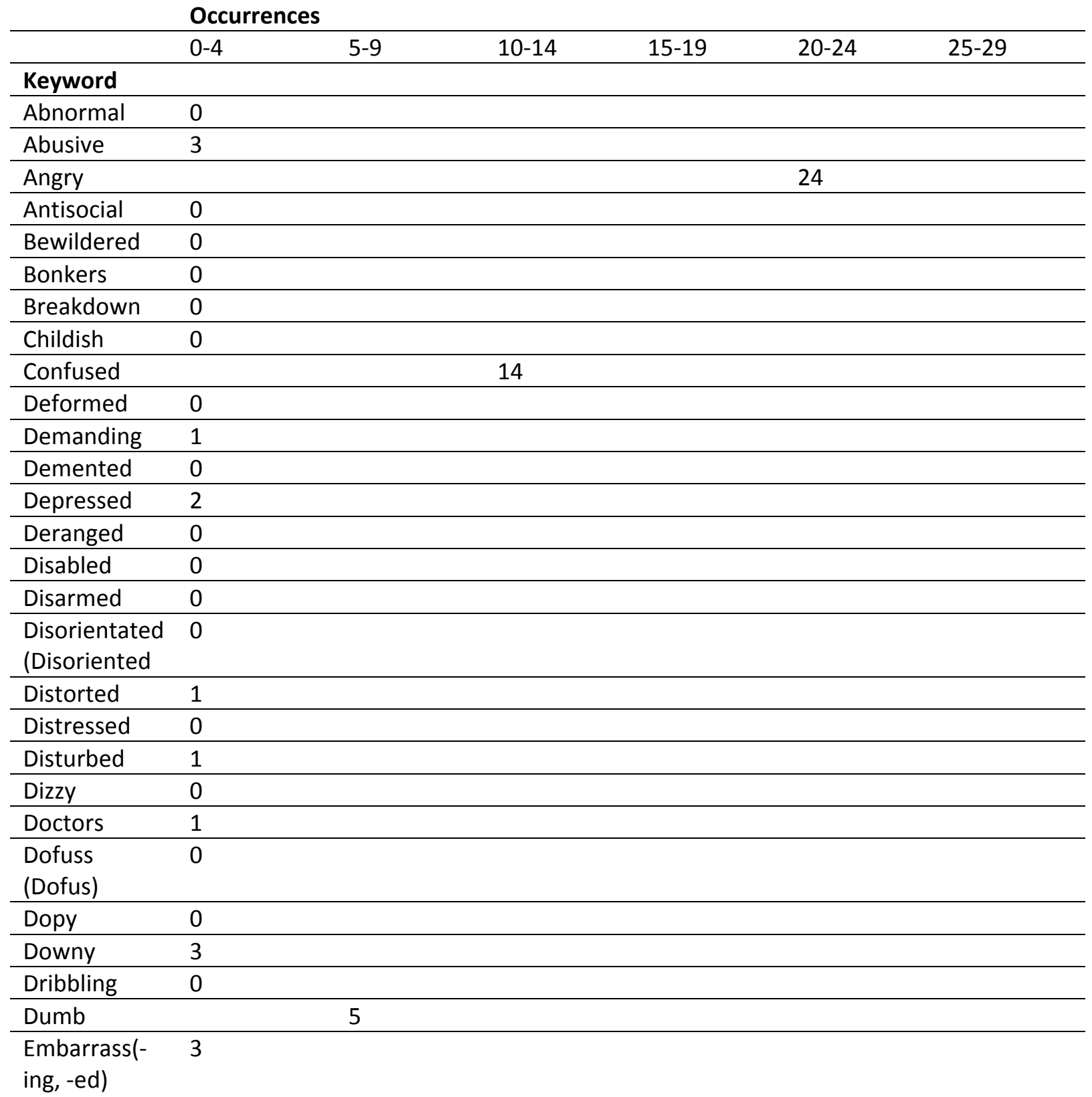


Portrayals of Mental Illness and Physical Disability in $21^{\text {st }}$ Century Children's Animation

Table 1 continued.

\begin{tabular}{|c|c|c|c|c|c|c|}
\hline & Occurrences & & & & & \\
\hline & $0-4$ & $5-9$ & $10-14$ & $15-19$ & $20-24$ & $25-29$ \\
\hline \multicolumn{7}{|l|}{ Keyword } \\
\hline Empty & & & 14 & & & \\
\hline Excluded & 0 & & & & & \\
\hline Feel Sorry & 2 & & & & & \\
\hline Fruit Cake & 0 & & & & & \\
\hline Frustrat(-ed, -ing) & 1 & & & & & \\
\hline Frustration & 0 & & & & & \\
\hline Funny & & & & & & 27 \\
\hline Goon & 0 & & & & & \\
\hline Halfwit & 0 & & & & & \\
\hline Hallucinating & 11 & & & & & \\
\hline Hallucination & 1 & & & & & \\
\hline Head Case & 0 & & & & & \\
\hline Helpless & & 6 & & & & \\
\hline $\begin{array}{l}\text { Hurting (yourself, } \\
\text { someone, anyone) }\end{array}$ & & 6 & & & & \\
\hline Idiot & & 9 & & & & \\
\hline III & 0 & & & & & \\
\hline Insane & 1 & & & & & \\
\hline Indecisive & 0 & & & & & \\
\hline Insecure & 0 & & & & & \\
\hline Intimidating & 1 & & & & & \\
\hline Irrational & 1 & & & & & \\
\hline Isolated & 2 & & & & & \\
\hline Jumpy & 1 & & & & & \\
\hline Lonely & 2 & & & & & \\
\hline Loony & 0 & & & & & \\
\hline Loser & 3 & & & & & \\
\hline Lunatic & 1 & & & & & \\
\hline Mad & & & & 16 & & \\
\hline Made fun of & 1 & & & & & \\
\hline Madness & 2 & & & & & \\
\hline Needing help & & & 11 & & & \\
\hline Nervous & & 6 & & & & \\
\hline Nightmares & & 9 & & & & \\
\hline Non-caring & 1 & & & & & \\
\hline None caring & 0 & & & & & \\
\hline $\begin{array}{l}\text { Numscull } \\
\text { (Numbskull) }\end{array}$ & 1 & & & & & \\
\hline Nutcase & 3 & & & & & \\
\hline Outcast & 3 & & & & & \\
\hline Psycho & 0 & & & & & \\
\hline Psychopath & 0 & & & & & \\
\hline Reject & 1 & & & & & \\
\hline Sad & & & 13 & & & \\
\hline
\end{tabular}

Scared 
Portrayals of Mental Illness and Physical Disability in $21^{\text {st }}$ Century Children’s Animation

Tahle 3: Total number of occurrences of kevwords in examined animations (30-70 orcurrences)

\begin{tabular}{|c|c|c|c|c|c|c|c|c|}
\hline & Occurrences & & & & & & & \\
\hline & $30-34$ & $35-39$ & $40-44$ & $45-50$ & $50-54$ & $55-59$ & $60-64$ & $65-70$ \\
\hline \multicolumn{9}{|l|}{ Keyword } \\
\hline Alone & & & & 46 & & & & \\
\hline Crazy & & & & & & & & 70 \\
\hline Dangerous & & & 41 & & & & & \\
\hline Lost & & & & & & 59 & & \\
\hline
\end{tabular}

The five keywords that appeared the most were “crazy” (70 times), "lost” (59 times), “alone” (46 times), “dangerous” (41 times), and “funny” (27 times). Keywords appeared in the animations a total of 462 times. Keywords that were repeated five or more times appeared 415 times throughout the animations. Of these 415 instances, 315 were overt, or direct, references, and 100 were covert, or implied references to mental illness or physical disability (Appendix B).

Each of the three animated movies had an approximate length of 90 minutes, with a combined run time of approximately 4.5 hours. Avatar: The Last Airbender, encompassed 61 episodes split into three seasons, with each episode having a length of approximately 30 minutes, with a combined run time of approximately 30.5 hours. An approximate total of 35 hours of animation was reviewed overall. An average of 13.2 keywords appeared for every hour of animation.

The keywords that appeared were normally used as descriptors for things that were actually happening. Rather than relying on connotative meanings that may have linked them to disability, keywords like "lost” and “dangerous” were more likely to be used literally to describe a certain situation. “Lost”, which appeared 59 times, was almost always used in instances during which the characters were actually lost or had lost something. Similarly, “dangerous”, which appeared 41 times, was used when the characters were at risk or were facing an enemy rather than being used to reference characters with disability. 
Portrayals of Mental Illness and Physical Disability in $21^{\text {st }}$ Century Children’s Animation

The exception was “crazy”, which appeared 70 times during analysis. “Crazy”, along with “insane”, was used almost exclusively to describe scenarios in which there was danger, in which the situation was getting out of hand, or in which one of the characters was behaving unusually or erratically. For example, in Frozen, an exchange between Anna and Kristoff occurs:

KRISTOFF: So tell me, what made the Queen go all ice-crazy?

ANNA: Oh, well, it was all my fault.

This is part of a bigger discussion about a breakdown Queen Elsa had during her coronation. Elsa loses control of her ice powers and freezes the kingdom in a display of power that the other characters were not aware Elsa possessed, and were uncertain how to respond. In episode 42 of Avatar, “The Headband”, Zuko visits his uncle, Iroh, who has been imprisoned for treason. Iroh has chosen not to speak to his nephew because he disagrees with the choices he has made in previous episodes. Zuko, frustrated that his uncle will not speak with him, shouts at him that he is “[...] a crazy old man! You're crazy! And if you weren't in jail, you'd be sleeping in a gutter.”

While “crazy” was often applied to an antagonistic force or a character that was behaving out of the ordinary, it was also used to describe the behavior of the protagonists or secondary character, as a descriptor for a dangerous or confusing situation, or to describe a character that possessed uncommon ingenuity or intelligence. For example, in How to Train Your Dragon 2, it is applied to the entire population of Berk by the main character, Hiccup:

“[Berk is] A bit trampled, busted and covered in ice, but it's home. It's our home. Those who attacked us are relentless and crazy. But those who stopped them, oh, even more so! We may be small in numbers, but we stand for something bigger than anything the world can pit against us. We are the voice of peace, and bit by bit, we will change this world.” 
Portrayals of Mental Illness and Physical Disability in $21^{\text {st }}$ Century Children's Animation In this excerpt, Hiccup is indeed applying the term "crazy" to the antagonists that opposed him and his people during the course of the film. However, by saying "but those who stopped them [...] even more so", Hiccup is implying that he and the people of Berk are more crazy than the antagonists. This implication is an admirable one because it is equating the word "crazy” with the feats of bravery, intelligence, and loyalty shown by the people of Berk throughout the rest of the film.

In addition to the use of keywords, each animation could be categorized by how it visually portrayed disability on screen (see Table 4). Each animation included the use of visual imagery that provided context for the keywords or presented images of disability on their own. The most overt images came from Avatar: the most common images that were portrayed were motions to imply insanity, most often by the twirling of a character's fingers next to their head. One instance of this occurs in episode 4, "The Warriors of Kyoshi”, when one of the main characters, Aang, dives into the ocean to swim with a school of massive fish called "elephant koi”. Another character, Sokka, makes a circular motion with his left hand near his left temple, signaling to his sister that he thinks Aang is crazy.

Other episodes gave direct references to blindness, normally through a visual gag that involved the blind character waving her hands in front of her eyes or pretending to read. In episode 37, “Lake Laogai”, the main characters are making missing posters for Aang’s lost pet. Sokka's attempt at a sketch is crude, causing the other characters to tease him in a drawn out gag that results in Toph using her blindness to tease him:

TOPH: (mockingly) It looks just like him to me!

SOKKA: Thank you, I worked really—(suddenly remembering that she is blind) Why do you feel the need to do that? 
Portrayals of Mental Illness and Physical Disability in $21^{\text {st }}$ Century Children’s Animation

More covert images included hand-wringing and physical isolation in Frozen, episodes of PTSD flashbacks in Wreck-It Ralph, and for the main character in How to Train Your Dragon 2 who walked with a prosthetic leg, a stiff gait on the side where the prosthetic was attached.

Because these animations target children, there are often substantial thematic and metaphoric elements at work. Rather than overtly addressing issues that parents may deem too “mature” for children, these animations often use stand-in words and images to portray similar themes. In Frozen, for example, Elsa is never openly stated as having any sort of anxiety disorder or physical disability. However, through the use of imagery and loaded vocabulary within the context of the animation, the audience is given signs that associate Elsa with similar themes of disability. For example, Elsa spends most of her childhood isolating herself from other people. As a result, she keeps her ice powers a secret from everyone in her kingdom, including her sister. After she uses them during her coronation, the Duke of Weselton, who has difficulty understanding her “condition”, refers to her as a “monster”. For this reason, several keywords specific to each animation were examined during analysis for their significance, including “blind”, “glitch”, and “peg-leg”.

In How to Train Your Dragon 2, the main character openly talks about his “peg-leg”: “Well, crazy thing is; I'm actually the one who shot him down. Hey, it’s... It's okay though, he got me back, right bud? You couldn't save all of me, could you? You just had to make it even so... Peg-leg!” In Avatar: The Last Airbender, Toph, a blind girl, both talks about the fact that she is blind and rebuffs the idea that she is "fragile” or "weak" because of her blindness: "Dad, I know it's probably hard for you to see me this way. But the obedient little helpless blind girl that you think I am just isn't me” (Episode 26, “The Blind Bandit). 
Portrayals of Mental Illness and Physical Disability in $21^{\text {st }}$ Century Children’s Animation

Other vocabulary is more covert, and works with thematic elements to create meaning. In Wreck-It Ralph, Vanellope, a main character, does not have a disability that can translate into the real world, and yet her "pixlexia" and "glitching” is obviously treated as a disability within the realm of her animation. When Vanellope is confronted by Taffyta for attempting to race with the other racers in her game, Taffyta becomes physically and verbally violent toward Vanellope. In one confrontation, Taffyta and her fellow racers push Vanellope to the ground while they tear apart the racing cart she made:

TAFFYTA: [...] Say I'm you. I'm in my weird little car, and I'm driving, and I actually feel kinda cool for once. And then, all of a sudden, oh no! I’m gl-gl-gl-glitching! [...]

See? You're an accident just waiting to happen.

Likewise, Elsa is never diagnosed as mentally ill, but her mantra of “conceal, don’t feel” combined with imagery of her isolating herself and wringing her hands when she becomes anxious suggest it. After the keywords were counted, each animation was examined individually for thematic and visual representations of disability.

\section{Frozen}

Keywords appeared in Disney’s Frozen 36 times (Appendix C), which constituted 7.7\% of all keywords used in all four animations. The keywords that appeared the most often were “crazy”, which appeared 9 times, and “dangerous”, which also appeared 9 times. The word “crazy” usually appeared when a character thought something was strange or unbelievable, rather than to reference an actual disability. For example, an exchange between Anna and Hans, her love interest, results in five of the 9 times “crazy” is used during the animation:

ANNA: Okay, can I just say something crazy?

HANS: I love crazy. 
Portrayals of Mental Illness and Physical Disability in $21^{\text {st }}$ Century Children’s Animation

In these cases, “crazy” is meant to mean "unbelievable” or "unexpected”. "Dangerous” was used by other characters to refer to Elsa: “She’s dangerous. Move quickly and with resolve.” It was also used to denote circumstances that risked the characters’ lives:

ANNA: Bring me my horse, please.

HANS: Anna, no. It's too dangerous.

Elsa, the deuteragonist and one of the princesses in Disney's Frozen, is never actually stated as having a mental or physical disability. However, there are strong visual and thematic elements within the animation that suggest that Elsa may be a representation of depression or a panic disorder. Elsa’s hand-wringing, pacing, and obviously distressed expressions throughout the animation are all images that can be associated with a panic or anxiety disorder. In addition, the way she isolates herself from her parents and sister and her loss of control under extreme stress, including the ice explosion she causes inside her room on the day of her parent's funeral, are all strong images. A large part of the plot of the animation revolves around Elsa's control of her ice powers; she was born with them, and is the only person in her kingdom that possesses them. As a result, no one can teach her how to deal with them in a healthy way. After an incident in which she inadvertently harms her younger sister, Anna, by accidentally freezing her, Elsa becomes withdrawn and afraid of her powers. Her parents, instead of finding a way to help her control them, teach her instead to pretend they don't exist. The lines “conceal, don’t feel” are a recurring mantra throughout the animation that Elsa uses whenever she tries to suppress her ice powers, suggesting that if she doesn't think about her powers, she will not be able to harm anyone.

She worries excessively about hurting others, reminiscent of a panic disorder, and the more fearful she becomes, the worse her powers react. When she is nervous during her 
Portrayals of Mental Illness and Physical Disability in $21^{\text {st }}$ Century Children’s Animation coronation and is forced to touch something with her bare hands, she coats it in a layer of frost. When she panics when her parents die and again when she realizes that she can't unfreeze her kingdom later in the animation, the audience is allowed to watch her powers build until she can no longer control them and they explode outward in a burst of ice and snow, which often harms the people around her in the process.

Panic disorders are often characterized by excessive worry, fear of death or loss of control, chills, and intense fear (Mayo Clinic Staff, 2012). Elsa is often shown wringing her hands, pacing, and repeatedly trying to keep her loved ones safe by isolating herself from them or warning them to stay away from her. Secondary characters often refer to Elsa as being “dangerous” or as a “monster”, suggesting a negative portrayal. However, Anna—who was harmed twice by Elsa's ice powers—-never calls Elsa a monster. In fact, she defends her from the people who want to imprison her for her powers and staunchly denies that Elsa is dangerous: “Elsa’s not dangerous. I’ll bring her back, and I’ll make this right” and “[...] my sister's not a monster."

In the end, it is Anna's unconditional love that breaks the winter Elsa's ice powers put on their kingdom when Anna throws herself in front Elsa before Hans can kill her:

ELSA: ...Y You sacrificed yourself for me?

ANNA: ...I love you.

OLAF: An act of true love will thaw a frozen heart.

ELSA: Love...will thaw... Love.... Of course.

This exchange, followed by Elsa's sudden insight as to how to thaw her kingdom, suggests that the unconditional support from her sister allowed Elsa to come to terms with her condition where her unhealthy coping strategies only failed. 
Portrayals of Mental Illness and Physical Disability in $21^{\text {st }}$ Century Children’s Animation

\section{How to Train Your Dragon 2}

Dreamwork’s How to Train Your Dragon 2 had 24 total appearances of keywords, accounting for of 5.1\% of the keywords that appeared in all four animations (Appendix D). The words that appeared the most often were "alone” or a form of "hurt(ing)”. “Alone” was used exclusively to denote the physical condition of being by one’s self: "I know I left you to raise Hiccup alone but I thought he'd be better off without me. And I was wrong, I see that now but...”

“Hurting” was used when one character was about to physically harm another, such as when Hiccup is attempting to snap his dragon, Toothless, out of the hypnotism of the Bewilderbeast: “It wasn’t your fault bud, they made you do it. You’d never hurt him, you'd never hurt me.”

Although it avoids using many of the keywords, How to Train Your Dragon represents physical disability through its use of imagery. The main character, Hiccup, is an amputee; he lost one of his legs in the previous animation. There is little mention of his lost limb; in fact, it is only mentioned twice, and both times by Hiccup himself. In one instance, he is playfully arguing with Toothless and makes passing reference to it: “Oh, come on, come on. Yeah-yeah. You wouldn't hurt a one legged_-” Hiccup is shown adjusting his peg-leg and using it to walk, run, and jump; the animation of his movement includes a stiff gait on the side of the amputation.

Hiccup’s dragon, Toothless, is also an amputee-Toothless lost half of his tail fin in the previous animation, and requires Hiccup's help to fly because his ability to steer in the air has been hindered. There is little mention of this "hindrance" in the animation. Instead, Hiccup works on ways to improve Toothless' flying capabilities and treats him as he does any other dragon: "We've really got to work on your solo flying there, bud. That, uh, locked up tail makes 
Portrayals of Mental Illness and Physical Disability in $21^{\text {st }}$ Century Children’s Animation for a pretty sloppy rescue maneuvers, hey?” There are other amputees in the animation as well— Drago, the villain, has lost an arm, and Gobber, one of the Vikings and a friend of Hiccup's, is missing a hand. Both of these characters are seen moving and going about tasks without major hindrance; Drago is a powerful fighter, and Gobber is a blacksmith.

\section{Wreck-It Ralph}

Disney’s Wreck-It Ralph used 35 keywords, accounting for 7.5\% of the total uses of keywords (Appendix E). The words that were used the most often were "alone” and "freak". Like in How to Train Your Dragon 2, “alone” appeared almost exclusively to denote the physical condition of being alone.

RALPH: I don’t know, I just.... I was just tired of living alone in the garbage.

GENE: Well now you can live alone in the penthouse.

While this “aloneness” contributed to part of the main character, Ralph’s, motivation, it was not used to reference disability. "Freak", on the other hand, was used exclusively to refer to someone or something that was different. The first three occurrences happen in succession when Vanellope and Ralph met for the first time:

VANELLOPE: Double stripes break, ga-doi. Hey, why are your hands so freakishly big? RALPH: Uh, I dunno. Why are you so freakishly annoying?

VANELLOPE: Well, why are you so freakishly_sweet mother of monkey milk! A gold coin!

The final use-_We're not going to hurt you, you little freak.”- -was in direct reference to Vanellope’s “glitching”, which is seen as an oddity by the rest of the characters.

Wreck-It Ralph gives the audience images of both a physical disability and a mental illness. Vanellope experiences what the characters term as "glitching”. This "glitching” leads 
Portrayals of Mental Illness and Physical Disability in $21^{\text {st }}$ Century Children's Animation other characters to ostracize her and prevents her from driving; attempts to learn how to race cause her to shudder and flicker, nearly resulting in an accident:

VANELLOPE: So, how'd I do?

RALPH: Um... well, you almost blew up the whole mountain.

VANELLOPE: Right, right, that's a good note.

RALPH: You've got to get that glitch under control, kid!

VANELLOPE: Okay, I will, I will! And then you think I got a chance?

Another character, Calhoun, experiences severe PSTD flashbacks that are triggered by the words "dynamite gal”. Earlier in the animation, one of the characters explains that "[i]t's not her fault. She's programmed with the most tragic back story ever. The one day she didn't do a perimeter check... her wedding day.” When Felix uses the words “dynamite gal”, Calhoun reacts angrily, and through a sequence of flashbacks the audience is shown that they serve as a trigger that sends her back the moment of her fiancé's death.

\section{Avatar: The Last Airbender}

With all three seasons combined, Avatar: The Last Airbender had the highest appearance rate of keywords out of all the animations, with 367 , or $79.4 \%$, of the total appearances. Of the 367 appearances that occurred in just the three seasons of Avatar alone, season one had 116, or $25.1 \%$, of total appearances, season two had 108, or 23,3\%, of total appearances, and season three had the highest appearance rate at 143, or 30.9\% (Appendix F).

The keywords that appeared the most frequently in season one and two were "lost" and "crazy". While "lost" was sometimes used to describe a state of confusion, it was frequently used to denote the physical condition of losing one's way. However, it was also used often as a euphemism for death, such as in episode 27, “Zuko Alone”, when Zuko is fending off soldiers 
Portrayals of Mental Illness and Physical Disability in $21^{\text {st }}$ Century Children’s Animation who want to draft a boy into the army: "You don't want Lee in your army - you're sick cowards messing with a family who's already lost one son to the war.”

“Crazy” was used both to imply that someone was mentally unstable and as a substitute for words like “outrageous” or “strange”. In episode 26, The Blind Bandit”, Aang refers to his friend Bumi when he tells Toph why he has come to see her: "Well, a crazy king told me I had to find an earthbender who listens to the earth. And then I had a vision in a magic swamp.” Earlier in the series, Aang speaks with the king of Omashu in episode 5, “The King of Omashu”, and is outraged by the demands of the king, who is holding his friends hostage: "I don't have time for your crazy games! Give me my friends back! We're leaving!”

In season 3, “crazy” was also one of the most frequent keywords; however, “alone” became the second-most frequent, and was usually used to denote instances where the characters physically alone or needed to accomplish something by themselves. An example of this is in episode 46, “The Avatar and the Fire Lord”, when Iroh tells Zuko of his ancestry and what his role in the war could be: "What happened generations ago can be resolved now, by you. Because of your legacy, you alone can cleanse the sins of our family and the Fire Nation. Born in you, along with all the strife, is the power to restore balance to the world.”

The imagery found in Avatar portrays a wide variety of disabilities in its character pool. Teo, a character from episode 17, “The Northern Air Temple”, is a skilled mechanic. He is also wheelchair-bound. However, the emphasis on his disability is only about how his father can make it easier for him to get around through the use of technology. Song, a character that appears in episode 22, “The Cave of Two Lovers,” is shown to have a badly burned leg.

Several supporting characters, such as an old herbalist woman, King Bumi of the Earth Kingdom, and Jeong Jeong, a retired Fire Nation general, are all described as being varying 
Portrayals of Mental Illness and Physical Disability in $21^{\text {st }}$ Century Children’s Animation degrees of "mad”, yet they all end up providing some kind of assistance that the main characters need. These characters aren’t always just one-time supporting cast, either. Teo reappears to help plan the raid on the Fire Kingdom in later seasons. Toph, who is one of the main characters, is blind and appears in nearly every episode of the second and third season.

Toph is not defined by her blindness. Her first appearance is at a wrestling ring, where she, a small, preteen girl, takes down an adult opponent many times her size and weight by her Earthbending prowess alone. She shows frustration at her parents' desire to keep her sheltered at home because they believe her blindness makes her helpless, and she corrects any character who assumes it makes her weak. As discussed previously, Toph’s blindness is not always mentioned, except when a situation comes up that makes it applicable-when the other characters are talking about something they read or saw, or when they are flying. In episode 18, “The Earth King”, Toph makes it known that she doesn't enjoy the flying because she doesn't have something solid underneath her feet: “Can we please buy a new saddle? Riding bareback is terrifying!”

In keeping with the theme of special powers being a metaphor for disability, an argument can be made that both "bending”, the process in which certain characters in Avatar are able to control wind, water, earth, and fire, and the inability to bend, could at different times be a metaphor for disability. In the world of Avatar, there is no apparent prejudice against "benders" or "non-benders"; benders are simply able to manipulate one of the four elements, whereas nonbenders cannot. However, during the series there are instances in which both are shown as hindrances. Sokka, the only non-bender in his travelling party, is often left out during fights while his friends take over with their bending. In episode 28, “The Chase”, he is left out of a fight because of his lack of bending:

TOPH: We can take 'em. Three on three. 
Portrayals of Mental Illness and Physical Disability in $21^{\text {st }}$ Century Children’s Animation SOKKA: Actually Toph, there's four of us.

TOPH: Oh, I'm sorry, I didn't count you; you know, no bending and all.

However, benders are shown to be powerless if they are separated from their element“Waterbenders” are unable to manipulate water during lunar eclipses, "Firebenders” are unable to manipulate fire during solar eclipses, and "Earthbenders” are unable to manipulate earth if they are at sea or surrounded by metal. In both regards, benders and non-benders can be “disabled”.

Both are also shown overcoming these disabilities. Azula, a villain in the second and third seasons, is a both a powerful firebender as well as a skilled fighter and manipulator. In episode 51, “The Day of Black Sun: Part 2”, there is an eclipse that temporarily takes away the powers of firebenders. However, she is shown evading Aang and his friends through her manipulation, in which she keeps them talking long enough for the eclipse to end and for her powers to return. In episode 44, “Sokka’s Master”, Sokka trains to learn how to use a sword and improve his fighting ability, and is later shown holding his own by using his fighting skills and quick-thinking against enemies who can bend the elements. In “The Northern Air Temple”, the group of main characters finds a town of non-benders who have adapted to life on a mountaintop by learning how to build gliders and use technology to their benefit.

\section{Discussion}

\section{Stereotypes}

On a whole, the images of the characters presented in these animations do not mesh with existing stereotypes. The “super crip”, “crazy villain” and "bitter cripple” stereotypes occur, but are all subverted or lamp-shaded in some way. Instead of disabled characters possessing powers and becoming “super crips”, the disabled characters in these animations are portrayed as people 
Portrayals of Mental Illness and Physical Disability in $21^{\text {st }}$ Century Children’s Animation whose powers sometimes cause them problems. Elsa possesses magical ice powers that allow her to freeze her entire kingdom, and has the potential to kill anyone who threatens her. However, she spends most of her animation trying to control or suppress them. The wringing of her hands, the self-isolation, and the fear of loss of control make her vulnerable. In addition, she is neither the heroine nor the villain in her story. Rather, her sister, Anna, is the heroine, and the audience is shown that Elsa is able to overcome her anxiety through the help of Anna's support, rather than through her self-imposed isolation.

Toph, too, is a powerful character. She is an accomplished Earthbender who can "see" through the vibrations in the ground, and eventually learns how to bend metal, a feat that is supposed to be impossible. She also possesses insecurities and faults. She openly expresses a dislike of flying and of sand, which hampers her senses. In "The Tales of Ba Sing Se”, she becomes upset when a pair of girls make fun of her cloudy eyes and her attempt to wear makeup, and several times throughout the series her blindness becomes an issue when the group needs to read something or, in one instance, needs to put up posters, which is played out comedically when Toph glues one face-down.

Azula, who is a villain, is shown to have manipulative, sociopathic tendencies. However, the reveal of her mental instability happens gradually over the course of many episodes, and is shown to be a product of her actions, not the cause of them.

In How to Train Your Dragon, Drago is indeed the villain, and the audience finds out that he lost his arm to dragons. However, Drago is the last amputee the audience sees in the animation; he is introduced as an antagonist who happens to be missing an arm, not as a man who is bad because he is missing that arm. In addition, we see Hiccup and Toothless first, and they are repeatedly juxtaposed with Drago as functional, sane, and hardworking characters. 
Portrayals of Mental Illness and Physical Disability in $21^{\text {st }}$ Century Children’s Animation

Calhoun continues to suffer from PTSD in Wreck-It Ralph, but the other characters take measures to avoid triggering her. Felix, her love interest, refrains from using the word “dynamite” after her initial episode, and during their wedding scene the attendees take measures to assure her that they would avoid the scenario that ended the life of her first fiancé.

This variety of characters has the possibility of doing two things. Presenting a range of diverse, complex characters with their own ambitions goes against the idea that disability can be defined by one or two set stereotypes. Viewers that are exposed to a wider range of characters will come to associate those characters by who they are rather than by their disability, and by presenting these characters as normal people, viewers will be less likely to project the generalized expectation of “super crip” or "mad” onto real people living with these disabilities. Presenting varied and realistic portrayals of disability and mental illness takes some of the uncertainty and stigma out of disability. By presenting disability as a part of normal life, it becomes less strange or frightening when viewers encounter instances of disability in real life, and people are more likely to define someone by their actions or personality rather than by their disability.

Second, by presenting a range of characters and a range of disability, it provides a more diverse representation for the disabled community and expands the number of characters to whom viewers can relate, including children. If the only character who has a disability is repeatedly the villain, it can correlate the malicious actions of the villain with the disability. Having villains become evil because they suddenly acquire a disability can likewise impede the acceptance of one's own disability as being a part of a person. Having a diverse representation of characters similar to themselves is an important factor to a child's development and self-esteem. Encountering well-rounded, capable disabled characters, including protagonists and secondary 
Portrayals of Mental Illness and Physical Disability in $21^{\text {st }}$ Century Children’s Animation

characters instead of only villains, could be key to a child's sense of self and self-worth, especially if they themselves have a disability.

\section{Social Cognitive and Cultivation Theory}

In addition to the portrayals of disability through images, the fact that only 20 of the 71 words examined showed up more than five times suggests that these animations are more likely to project a positive portrayal of disability. Though about a fourth of the total appearances of these words were covert ones used to apply words associated to disability to other circumstances, most of the appearances were overt ones, meaning that they were being used in the sense of their literal definitions. The biggest exception to this was "crazy”, which included "mentally unstable" as part of its literal definition.

Rose, Thornicroft, Pinfold, and Kassam’s study (2007) collected its list of words from 14 year old children, who had learned to associate these words with mental illness. Because only twenty of these words were used with regularity in these four animations, the target audience, who are preteen children and adolescents in their formative years, are exposed to fewer of them.

According to social cognitive theory, being exposed at an early age to fewer verbal cues that suggest physical disability and mental illness is associated with negativity or danger would create the idea that disability was normal and not something to be feared. Instead of encouraging stereotypes like the "super crip” to arise and perpetuate, portrayals of disability would be more normalized. In the same way, presenting social cues for how to act around someone with a disability through the visual images in these animations remove some of the uncertainty of how to act in the real world. Disabled characters that are portrayed going about their lives as normal people with normal problems, dealing with their disabilities in healthy ways, and having other 
Portrayals of Mental Illness and Physical Disability in $21^{\text {st }}$ Century Children’s Animation characters react to the disabilities of others in healthy ways, promotes the idea in viewers that people who share these sorts of disabilities in the real world are normal.

Cultivation theory would suggest that repeated exposure to these keywords would give them the sense of being standard; in the same way that children become desensitized to repeated exposure to swearing from television, they become desensitized to the negative implications words like "crazy" or "freak" have in regards to disability. Because the keywords found in these animations were used sparingly, or for their literal definition, these animations avoid placing negative connotations on the disabled characters they portray. Although “crazy” and "dangerous” were used to often refer to disability, they were also used to in situations that did not have stereotypical connotations for disabled characters. The high usages of these words suggests that stigmatization of disabled characters still exist in these animations, but they are also paired with images that support diverse representations of disabled characters.

Over time, repeated exposure to these words—or the lack thereof—-would encourage viewers not to think of them by their connotative meanings, and to question their use in conjunction with disability. By avoiding an abundance of language that stigmatizes the characters for their disabilities, and by presenting images of realistic and varied character interactions, these animations have the potential to teach children that people with disabilities should be treated the same as everyone else.

My methodological approach has three limitations. First, because only three featurelength animated movies and a 61 episode animated series were used in the study, the sample size of the animations analyzed in this study was small. However, the animations were taken from a variety of companies who all create content for children and who all are well known around the world. The children who watch these animations internalize them as part of their childhood, and 
Portrayals of Mental Illness and Physical Disability in $21^{\text {st }}$ Century Children’s Animation so the use of images and choice of language by these companies in these animated features may have an impact on children's social development. The second limitation is that the British study I derived my list of keywords from both targeted mental illness only, and contained many British English words that the American English dialect does not normally use. However, the words that I chose to use are common in American English, provide the same connotations to children when they appear in media, and were easily generalized to include physical disability as well as mental illness. The third limitation was the division between what was and was not an overt reference. Depending on the context, some words could arguably have multiple or vague meanings, which make coding for "overtness" or "covertness” difficult. An example of this is the word "crazy”, which could sometimes refer literally to someone who seemed to be mentally ill, be used as a substitute for "unbelievable” or "surprising”, or even both at once when referring to a specific character who was in the process of performing an action that appeared to be out of the ordinary.

Further research could examine a wider range of children's animation beyond the three animated movies and one animated series handled in this study. By increasing the range of animation, the scope of the keywords in this study could be examined on a larger scale. This would provide a more in-depth look at the words and images that children are exposed because it would include cartoons and movies that children are exposed to on a daily or weekly basis. In addition, a study similar to Rose, Thornicroft, Pinfold, and Kassam’s study (2007) could be performed with children to determine whether or not the same associations are being made with these words and disability.

Media scholars should examine the representation of disability as it is portrayed in other media. The stereotypes of disability that exist within media are not always obvious, but they can be evoked with language as innocuous as “disturbed” or "ill”. Language that stereotypes 
Portrayals of Mental Illness and Physical Disability in $21^{\text {st }}$ Century Children’s Animation disability has become a part of vernacular: Words like “crazy”, “idiot”, and “insane” are applied in everyday conversation with little regard to their origins or their connotations.

Parents with small children should be aware that their child's consumption of media may influence the behaviors they learn and the ideas they develop about the world around them. Parents should take steps to limit the amount of media their child watches each day, watch television and movies with them, and make efforts to discuss the images and language that appear in them. By monitoring their child's media and entering into discussions about its content, parents would be able to assert a degree of control over the perceptions that may be cultivated over time. 
Portrayals of Mental Illness and Physical Disability in $21^{\text {st }}$ Century Children's Animation

References

Bandura, A. (2001). SOCIAL COGNITIVE THEORY: An Agentic Perspective. Annual Review of Psychology. Vol. 52: 1-26 (Volume publication date February 2001).

DOI: 10.1146/annurev.psych.52.1.1. Retrieved from: http://www.annualreviews.org/doi/full/10.1146/annurev.psych.52.1.1

Bernstein, R. (2012). Nearly 1 in 5 People Have a Disability in the U.S., Census Bureau Reports. United States Census Bureau Newsroom Archive. Retrieved from https://www.census.gov/newsroom/releases/archives/miscellaneous/cb12-134.html

Black, R. S. \& Pretes, L (2007). Victims and victors: Representation of physical disability on the silver screen. RESEARCH AND PRACTICE FOR PERSONS WITH SEVERE DISABILITIES. Volume: 32 Issue: 1 Pages: 66-83

Box Office Mojo, (2014). 2014 DOMESTIC GROSSES [Data file]. Retrieved from http://www.boxofficemojo.com/yearly/chart/?yr=2014

Box Office Mojo. (2014). How to Train Your Dragon 2. Retrieved from http://www.boxofficemojo.com/movies/?id=howtotrainyourdragon2.htm

Box Office Mojo. (2013). Frozen. Retrieved from http://boxofficemojo.com/movies/?id=frozen2013.htm

Box Office Mojo. (2012). Wreck-It Ralph. Retrieved from http://www.boxofficemojo.com/movies/?id=rebootralph.htm

DC Comics. (2014). Joker. Characters. Retrieved from http://www.dccomics.com/characters/joker

Denler, H, Wolters, C, Benzon, M. (2014). Social Cognitive Theory. Education.com http://www.education.com/reference/article/social-cognitive-theory/ 
Portrayals of Mental Illness and Physical Disability in $21^{\text {st }}$ Century Children’s Animation

Dubriel, J. (2006). Dubriel, Joni G V, "The Television Portrayals of African Americans and Racial Attitudes" Communication Theses. Paper 3

GLAAD. (2013). People with Disabilities. Where We Are On TV, 2013, p. 18. Retrieved from http://www.glaad.org/files/2013WWATV.pdf

Harris, R. J. (2009). A Cognitive Psychology of Mass Communication: Fifth Edition. New York, New York: Routledge Taylor and Francis Group

Lam, S. K. S. (2011). The impact of digitalization on cinematic aesthetics and the 'spectrum of cultural representations': The case of hong kong. Dissertation Abstracts International, Section A: The Humanities and Social Sciences. (Order No. DA3497741, Chinese U of Hong Kong). Retrieved from http://search.proquest.com/docview/1353033143?accounti d=14665. (1353033143; 2013420416).

Laroi, F \& Van der Linden, M. (2009). The effects of a documentary film on reducing stigmatisation about schizophrenia PSYCHOSIS-PSYCHOLOGICAL SOCIAL AND INTEGRATIVE APPROACHES. Volume: 1 Issue: 1 Pages: 61-7

DOI: $10.1080 / 17522430802578395$

Lawson, A., Fouts, G., (2004). Mental Illness in Disney Animated Films, Canadian Journal of Psychiatry. May2004, Vol. 49 Issue 5, p310-314. 5p. http://web.b.ebscohost.com/ehost/pdfviewer/pdfviewer?sid=79ce3360-7cfa-4408-86d5c3534d6c8695\%40sessionmgr110\&vid=1\&hid=112

Marris, P. \& Thornham, S. (2000). Media Studies: A Reader. New York, NY: New York University Press

Marvel. (2014). Daredevil. Characters. Retrieved from 
Portrayals of Mental Illness and Physical Disability in $21^{\text {st }}$ Century Children's Animation http://marvel.com/characters/11/daredevil

Mayo Clinic Staff. (2012). Mayo Clinic: Panic Attacks and Panic Disorders. Symptoms. Retrieved from http://www.mayoclinic.org/diseases-conditions/panicattacks/basics/symptoms/con- 20020825

McCombs, M. E. \& Shaw, D. L. (1972). THE AGENDA-SETTING FUNCTION OF MASS MEDIA. [Abstract]. American Association for Public Opinion Research. Retrieved from http://poq.oxfordjournals.org/content/36/2/176.abstract

Medjesky, C. (2008). Disabusing Disability: Negotiating Disability Identity Through Anecdote. Conference Papers -- National Communication Association. Retrieved from http://search.ebscohost.com.echo.louisville.edu/login.aspx?direct=true\&db=ufh\&AN=44 852419\&site=ehost-live

Parmer, N. \& Neil. (2004). Lunatic Toons. Psychology Today. Sep/Oct2004, Vol. 37 Issue 5, p33-33. 1/5p. Retrieved from http://web.b.ebscohost.com/ehost/pdfviewer/pdfviewer?vid=4\&sid=7d778669-bcda4835-a5b1-6c106b4f6e2f\%40sessionmgr112\&hid=112

Preidt, R. (2014). 1 in 5 Adults Dealt With Mental Illness in 2013. WebMd. Retrieved from http://www.webmd.com/mental-health/news/20141120/1-in-5-us-adults-dealt-with-amental-illness-in-2013

Quinlan, M. M., \& Bates, B. R. (2010). Are our president learning? Unpacking the enthymematic connections in the speech mistakes of President George W. Bush. Journal of Research in Special Educational Needs, 10(1), 3-12. doi: 10.1111=j.1471-3802.2009.01132.x

Ricke, L. D. (2012). Funny or Harmful?: Derogatory Speech on Fox’s Family Guy. Communication Studies, 63(2), 119-135. doi:10.1080/10510974.2011.638412. 
Portrayals of Mental Illness and Physical Disability in $21^{\text {st }}$ Century Children's Animation

Retrieved from http://search.ebscohost.com.echo.louisville.edu/login.aspx

?direct=true\&db=ufh\&AN=73763529\&site=ehost-live

Rose, D., Thornicroft, G., Pinfold, V. \& Kassam, A. (2007). 250 labels used to stigmatise people with mental illness. BMC Health Services Research. Retrieved from http://www.biomedcentral.com.echo.louisville.edu/1472-6963/7/97

Shrum, L. J., Burroughs, E. J., Rindfleisch, A. (2005). Television’s Cultivation of Material Values. Journal of Consumer Research, Vol. 32, No. 3 pp. 473-479. The University of Chicago Press. Retrieved from http://faculty.business.utsa.edu/ljshrum/JCR\%202005.pdf

Stice, E. \& Shaw, H. E. (1994). Adverse Effects of the Media Portrayed Thin-Ideal on Women and Linkages to Bulimic Symptomatology. Journal of Social and Clinical Psychology: Vol. 13, No. 3, pp. 288-308. doi: 10.1521/jscp.1994.13.3.288

Strasburger, V. C. \& Wilson, B. J., \& Jordan, A. B. (2009). Children, Adolescents, and the Media, Second Edition. California: SAGE Publications

The Nielson Company. (n.d.). TELEVISION. Nielson Solutions. Retrieved from http://www.nielsen.com/us/en/solutions/measurement/television.html

The Nielson Company. (2013). NIELSEN ESTIMATES 115.6 MILLION TV HOMES IN THE U.S., UP 1.2\%. Nielson Newswire. Retrieved from http://www.nielsen.com/us/en/insights/news/2013/nielsen-estimates-115-6-million-tvhomes-in-the-u-s---up-1-2-.html

The Nielson Company. (2014). STATE OF THE MEDIA: AUDIO TODAY Q3 2014. Nielson Newswire. Retrieved from http://www.nielsen.com/us/en/insights/reports/2014/state-of-the-media-audio-today-q32014.html 
Portrayals of Mental Illness and Physical Disability in $21^{\text {st }}$ Century Children’s Animation Wahl, O., (2003). Depictions of mental illnesses in children’s media. George Mason University, Fairfax, USA, http://web.b.ebscohost.com/ehost/pdfviewer/pdfviewer?sid=722cef98558d-4cbc-94ae-57e56eabdb90\%40sessionmgr115\&vid=0\&hid=112

Weitzer, R. \& Kubrin, C. E. (2004). BREAKING NEWS: HOW LOCAL TV NEWS AND REAL-WORLD CONDITIONS AFFECT FEAR OF CRIME. Justice Quarterly: JQ; Sep 2004; 21, 3; Law Module pg. 497. Retrieved from www.gwu.edu/ soc/docs/Weitzer/Breaking_News.pdf

Zhang, L., \& Haller, B. (2013). Consuming Image: How Mass Media Impact the Identity of People with Disabilities.Communication Quarterly, 61(3), 319-334. doi:10.1080/01463373.2013.776988. Retrieved from http://search.ebscohost.com.echo.louisville.edu/login.aspx?direct=true\&db=ufh\&AN=88 212636\&site=ehost-live 
Portrayals of Mental Illness and Physical Disability in $21^{\text {st }}$ Century Children’s Animation

Appendix A

Orginal 250 word list compiled by Rose, Thornicroft, Pinfold, \& Kassam.

\begin{tabular}{|c|c|c|c|}
\hline Abnormal & Frustration & Not fair & $\begin{array}{l}\text { Sometimes lacking brain } \\
\text { power }\end{array}$ \\
\hline Abusive & Fucked & Not happy & Spakka \\
\hline Alone & Funny & Not obvious & Spanner \\
\hline Alzheimers & Gay & Not quite there & Spastic \\
\hline Angry & Get lost & Not the sharpest knife in the drawer & Spaz \\
\hline Anti-social & Gone in the head & Numscull & Split personality \\
\hline Asylums & Goon & Nutcase & Spoone \\
\hline Attention seekers & Green room & Nutter & Stiggy nutter \\
\hline Autism & Halfwit & Nuts & Stigma \\
\hline Bewildered & Hallucinating & Nutty as a fruitcake & Strait jackets \\
\hline Bimbo & Hallucinations & OCD & Strange \\
\hline Bonkers & Hand fed & Odd & Stress \\
\hline Brain damage & Handicapped & Oddball & Stressed \\
\hline Brain dead & Happy club & Off their rocker & Therapist \\
\hline Breakdown & Hard & Out of it & Therapy \\
\hline Childish & Hard work & Outcast & Thick \\
\hline Cola sweat & Head banging & Padded cells & Thicko \\
\hline Confused & Head case & Paedophile & Thicky \\
\hline Crackers & Helpless & Panicked & Tiring \\
\hline Crazy & Hurting yourself & Paranoid & Too much pressure \\
\hline Cushioned walks & Idiot & Patch Adams & Touchy to talk to \\
\hline Dangerous & Ill & People who are obsessed & Troubled \\
\hline Deformed & Indecisive & Perfectly normal & Twisted \\
\hline Demanding & Infixed in bad habits & Perverted & Twister \\
\hline Demented & Insane & Physical problems & Ugly \\
\hline Depressed & Insecure & Physically ill & Unable to make decisions \\
\hline Depression & Intellectually challenged & Pills & Unappreciated \\
\hline Deranged & Intimidating & Pinflump & Unapproachable \\
\hline Difficulty learning & Irrational & Pive & Uncomfortable \\
\hline Dildo & Isolated & Plank & Under pressure \\
\hline Dinlo & Joe from Eastenders & Ponce & Understandable \\
\hline Disabled & Jumpy & Pressure & Unfair \\
\hline Disarmed & Learning difficulties & Pressurising families & Unfortunate \\
\hline Disorientated & Lonely & Problems & Unhappy \\
\hline Distorted & Loony & Psychiatric & Unpredictable \\
\hline Distressed & Loony bin & Psychiatric health & Unstable \\
\hline Distressing & Loser & Psychiatrist & Upsetting \\
\hline Disturbed & Lost & Psycho & Veg \\
\hline Disturbing & Lunatic & Psychopath & Vegetable \\
\hline Disturbing images & Mad & Reject & Victim \\
\hline Div & Made fun of & Retard & Victimised \\
\hline Dizzy & Madness & Sad & Violence \\
\hline Doctors & Manic depression & Sandwich/pepperoni short of a picnic & Violent \\
\hline Dofuss & Mass murderers & Scared & Voices \\
\hline Dopy & M.E. & $\begin{array}{l}\text { Scared to talk to if they were a murderer } \\
\text { or rapist }\end{array}$ & Voices in your head \\
\hline Downy & Mental & Scary & Vulnerable \\
\hline Dribbling & Mental hospital & Schizo & Wacky \\
\hline Drugged-up & Mental illness & Schizophrenia & Wally \\
\hline Dulally & Mental institution & Schizophrenic & War \\
\hline Dumb & Mentally challenged & School can cause it & Wheelchair jockey \\
\hline Embarrassed & Mentally handicapped & School pressure & Weird \\
\hline Embarrassing & Mentally ill & Screw loose & Weirdo \\
\hline Empty & Misunderstood & Screwed & Wheel chairs \\
\hline Escaped from an asylum & Mong & Sees things in a different way & White coats \\
\hline Excluded & $\begin{array}{l}\text { More common than you } \\
\text { think }\end{array}$ & Segregation & Wild \\
\hline Feel sorry & Muppets & Self-harm & Wild funny noises \\
\hline $\begin{array}{l}\text { Few sandwiches short of a } \\
\text { picnic basket }\end{array}$ & Needing help & Shock syndrome & Window licker \\
\hline Flid & Nervous & Shouts & Withdrawn \\
\hline Flip in the head & Nightmares & Sick in the head & World of their own \\
\hline Freak & Non-caring & Simple & Worried \\
\hline Fruit cake & None caring & Simpleton & You belong in a home \\
\hline Frustrated & No-one upstairs & Some people born mentally ill & \\
\hline Frustrating & Not all there & Sometimes includes drugs & \\
\hline
\end{tabular}


Portrayals of Mental Illness and Physical Disability in $21^{\text {st }}$ Century Children's Animation

\section{Appendix B}

Number of overt and covert references of the 20 keywords that appeared 5 or more times during analysis of the animations.

\begin{tabular}{lrrrr} 
Keyword: & Overt References & Covert References & Total References \\
\hline Alone & 37 & 9 & 46 \\
\hline Angry & 21 & 3 & 24 \\
\hline Confused & 13 & 4 & 17 \\
\hline Crazy & 36 & 34 & 70 \\
\hline Dangerous & 35 & 6 & 41 \\
\hline Dumb & 3 & 2 & 5 \\
\hline Empty & 13 & 1 & 14 \\
\hline Freak & 9 & 3 & 12 \\
\hline Funny & 22 & 5 & 27 \\
\hline Helpless & 6 & 0 & 6 \\
\hline Hurting (yourself, & 6 & 0 & 6 \\
oneself) & & & \\
\hline Idiot & 8 & 1 & 9 \\
\hline Lost & 40 & 19 & 59 \\
\hline Mad & 13 & 3 & 16 \\
\hline Needing Help & 11 & 0 & 11 \\
\hline Nervous & 5 & 1 & 6 \\
\hline Nightmares & 5 & 4 & 9 \\
\hline Sad & 8 & 5 & 13 \\
\hline Scared & 19 & 0 & 19 \\
\hline Scary & 5 & 0 & 5 \\
\hline Total: & 315 & 100 & 415
\end{tabular}


Portrayals of Mental Illness and Physical Disability in $21^{\text {st }}$ Century Children's Animation

Appendix C

Number of appearances of keywords in Disney’s Frozen.

\begin{tabular}{|c|c|c|c|c|c|}
\hline Keyword & Total & Keyword & Total & Keyword & Total \\
\hline Abnormal & 0 & Funny & 1 & Scared & 3 \\
\hline Abusive & 0 & Goon & 0 & Scary & 0 \\
\hline Alone & 2 & Halfwit & 0 & Screw loose & 0 \\
\hline Angry & 0 & Hallucinating & 0 & & \\
\hline Antisocial & 0 & Hallucination & 0 & & \\
\hline Bewildered & 0 & Head case & 0 & Total: & 36 \\
\hline Bonkers & 0 & Helpless & 0 & & \\
\hline Breakdown & 0 & $\begin{array}{l}\text { Hurting (yourself, someone, } \\
\text { anyone) }\end{array}$ & 1 & & \\
\hline Childish & 0 & Idiot & 0 & & \\
\hline Confused & 0 & III & 0 & & \\
\hline Crazy & 9 & Insane & 0 & & \\
\hline Danger(ous) & 9 & Indecisive & 0 & & \\
\hline Deformed & 0 & Insecure & 0 & & \\
\hline Demanding & 0 & Intimidating & 0 & & \\
\hline Demented & 0 & Irrational & 0 & & \\
\hline Depressed & 0 & Isolated & 2 & & \\
\hline Deranged & 0 & Jumpy & 0 & & \\
\hline Disabled & 0 & Lonely & 1 & & \\
\hline Disarmed & 0 & Loony & 0 & & \\
\hline $\begin{array}{l}\text { Disorientated } \\
\text { (Disoriented) }\end{array}$ & 0 & Loser & 0 & & \\
\hline Distorted & 0 & Lost & 1 & & \\
\hline Distress(ed, -ing) & 0 & Lunatic & 0 & & \\
\hline Disturbed & 0 & Mad & 3 & & \\
\hline Dizzy & 0 & Made fun of & 0 & & \\
\hline Doctors & 1 & Madness & 0 & & \\
\hline Dofuss (Dofus) & 0 & Misunderstood & 0 & & \\
\hline Dopy & 0 & Needing help & 0 & & \\
\hline Down(y) & 0 & Nervous & 0 & & \\
\hline Dribbling & 0 & Nightmares & 0 & & \\
\hline Dumb & 1 & Non-caring & 0 & & \\
\hline Embarrass(ed, -ing) & 0 & None caring & 0 & & \\
\hline Empty & 2 & Numscull (Numbskull) & 0 & & \\
\hline Excluded & 0 & Nutcase & 0 & & \\
\hline Feel sorry & 0 & Outcast & 0 & & \\
\hline Freak & 0 & Psycho & 0 & & \\
\hline Fruit cake & 0 & Psychopath & 0 & & \\
\hline Frustrat(ed, -ing) & 0 & Reject & 0 & & \\
\hline Frustration & 0 & Sad & 0 & & \\
\hline
\end{tabular}


Portrayals of Mental Illness and Physical Disability in $21^{\text {st }}$ Century Children's Animation

Appendix D

Number of appearances of keywords in Dreamworks How to Train Your Dragon 2

\begin{tabular}{|c|c|c|c|c|c|}
\hline 'eyword & Total & Keyword & Total & Keyword & Total \\
\hline Ibnormal & 0 & Funny & 1 & Scared & 2 \\
\hline Ibusive & 0 & Goon & 0 & Scary & 0 \\
\hline lone & 5 & Halfwit & 0 & Screw loose & 0 \\
\hline ingry & 0 & Hallucinating & 0 & & \\
\hline intisocial & 0 & Hallucination & 0 & & \\
\hline iewildered & 0 & Head case & 0 & Total: & 24 \\
\hline ionkers & 0 & Helpless & 0 & & \\
\hline sreakdown & 0 & $\begin{array}{l}\text { Hurting (yourself, someone, } \\
\text { anyone) }\end{array}$ & 5 & & \\
\hline :hildish & 0 & Idiot & 0 & & \\
\hline :onfused & 0 & III & 0 & & \\
\hline razy & 3 & Insane & 0 & & \\
\hline langer(ous) & 1 & Indecisive & 0 & & \\
\hline leformed & 0 & Insecure & 0 & & \\
\hline Jemanding & 0 & Intimidating & 0 & & \\
\hline lemented & 0 & Irrational & 0 & & \\
\hline lepressed & 0 & Isolated & 0 & & \\
\hline leranged & 0 & Jumpy & 0 & & \\
\hline isabled & 0 & Lonely & 0 & & \\
\hline )isarmed & 0 & Loony & 0 & & \\
\hline \multicolumn{6}{|l|}{ )isorientated } \\
\hline )istorted & 0 & Lost & 2 & & \\
\hline )istress(ed, -ing) & 0 & Lunatic & 1 & & \\
\hline )isturbed & 0 & Mad & 1 & & \\
\hline izzy & 0 & Made fun of & 0 & & \\
\hline octors & 0 & Madness & 0 & & \\
\hline ofuss (Dofus) & 0 & Misunderstood & 0 & & \\
\hline lopy & 0 & Needing help & 0 & & \\
\hline Jown(y) & 0 & Nervous & 0 & & \\
\hline ribbling & 0 & Nightmares & 1 & & \\
\hline umb & 0 & Non-caring & 0 & & \\
\hline :mbarrass(ed, -ing) & 0 & None caring & 0 & & \\
\hline impty & 2 & Numscull (Numbskull) & 0 & & \\
\hline xcluded & 0 & Nutcase & 0 & & \\
\hline eel sorry & 0 & Outcast & 0 & & \\
\hline reak & 0 & Psycho & 0 & & \\
\hline ruit cake & 0 & Psychopath & 0 & & \\
\hline rustrat(ed, -ing) & 0 & Reject & 0 & & \\
\hline rustration & 0 & Sad & 0 & & \\
\hline
\end{tabular}


Portrayals of Mental Illness and Physical Disability in $21^{\text {st }}$ Century Children’s Animation

\section{Appendix E}

Number of appearances of keywords in Disney’s Wreck-It Ralph

\begin{tabular}{|c|c|c|c|c|c|}
\hline Keyword & Total & Keyword & Total & Keyword & Total \\
\hline Abnormal & 0 & Funny & 3 & Scared & 1 \\
\hline Abusive & 0 & Goon & 0 & Scary & 0 \\
\hline Alone & 8 & Halfwit & 0 & Screw loose & 0 \\
\hline Angry & 1 & Hallucinating & 0 & & \\
\hline Antisocial & 0 & Hallucination & 0 & & \\
\hline Bewildered & 0 & Head case & 0 & Total: & 35 \\
\hline Bonkers & 0 & Helpless & 0 & & \\
\hline Breakdown & 0 & $\begin{array}{l}\text { Hurting (yourself, someone, } \\
\text { anyone) }\end{array}$ & 0 & & \\
\hline Childish & 0 & Idiot & 1 & & \\
\hline Confused & 0 & III & 0 & & \\
\hline Crazy & 2 & Insane & 0 & & \\
\hline Danger(ous) & 1 & Indecisive & 0 & & \\
\hline Deformed & 0 & Insecure & 0 & & \\
\hline Demanding & 0 & Intimidating & 0 & & \\
\hline Demented & 0 & Irrational & 0 & & \\
\hline Depressed & 0 & Isolated & 0 & & \\
\hline Deranged & 0 & Jumpy & 0 & & \\
\hline Disabled & 0 & Lonely & 0 & & \\
\hline Disarmed & 0 & Loony & 0 & & \\
\hline $\begin{array}{l}\text { Disorientated } \\
\text { (Disoriented) } \\
\end{array}$ & 0 & Loser & 0 & & \\
\hline Distorted & 0 & Lost & 3 & & \\
\hline Distress(ed, -ing) & 0 & Lunatic & 0 & & \\
\hline Disturbed & 0 & Mad & 0 & & \\
\hline Dizzy & 0 & Made fun of & 0 & & \\
\hline Doctors & 0 & Madness & 0 & & \\
\hline Dofuss (Dofus) & 0 & Misunderstood & 1 & & \\
\hline Dopy & 0 & Needing help & 3 & & \\
\hline Down(y) & 0 & Nervous & 1 & & \\
\hline Dribbling & 0 & Nightmares & 1 & & \\
\hline Dumb & 1 & Non-caring & 0 & & \\
\hline Embarrass(ed, -ing) & 0 & None caring & 0 & & \\
\hline Empty & 0 & Numscull (Numbskull) & 1 & & \\
\hline Excluded & 0 & Nutcase & 1 & & \\
\hline Feel sorry & 0 & Outcast & 0 & & \\
\hline Freak & 4 & Psycho & 0 & & \\
\hline Fruit cake & 0 & Psychopath & 0 & & \\
\hline Frustrat(ed, -ing) & 0 & Reject & 1 & & \\
\hline Frustration & 0 & Sad & 1 & & \\
\hline
\end{tabular}


Portrayals of Mental Illness and Physical Disability in $21^{\text {st }}$ Century Children's Animation

Appendix F

Number of kevwords that appear in all three seasons of Avatar: The Last

\begin{tabular}{|c|c|c|c|c|c|}
\hline Keyword & Total & Keyword & Total & Keyword & Total \\
\hline Abnormal & 0 & Funny & 22 & Scared & 13 \\
\hline Abusive & 3 & Goon & 0 & Scary & 5 \\
\hline Alone & 31 & Halfwit & 0 & Screw loose & 0 \\
\hline Angry & 23 & Hallucinating & 1 & & \\
\hline Antisocial & 0 & Hallucination & 1 & & \\
\hline Bewildered & 0 & Head case & 0 & Total: & 367 \\
\hline Bonkers & 0 & Helpless & 6 & & \\
\hline Breakdown & 0 & $\begin{array}{l}\text { Hurting (yourself, someone, } \\
\text { anyone) }\end{array}$ & 0 & & \\
\hline Childish & 0 & Idiot & 8 & & \\
\hline Confused & 17 & III & 0 & & \\
\hline Crazy & 56 & Insane & 1 & & \\
\hline Danger(ous) & 30 & Indecisive & 0 & & \\
\hline Deformed & 0 & Insecure & 0 & & \\
\hline Demanding & 1 & Intimidating & 1 & & \\
\hline Demented & 0 & Irrational & 1 & & \\
\hline Depressed & 2 & Isolated & 0 & & \\
\hline Deranged & 0 & Jumpy & 1 & & \\
\hline Disabled & 0 & Lonely & 1 & & \\
\hline Disarmed & 0 & Loony & 0 & & \\
\hline $\begin{array}{l}\text { Disorientated } \\
\text { (Disoriented) }\end{array}$ & 0 & Loser & 3 & & \\
\hline Distorted & 1 & Lost & 53 & & \\
\hline Distress(ed, -ing) & 0 & Lunatic & 0 & & \\
\hline Disturbed & 1 & Mad & 12 & & \\
\hline Dizzy & 0 & Made fun of & 1 & & \\
\hline Doctors & 0 & Madness & 2 & & \\
\hline Dofuss (Dofus) & 0 & Misunderstood & 2 & & \\
\hline Dopy & 0 & Needing help & 8 & & \\
\hline Down(y) & 3 & Nervous & 5 & & \\
\hline Dribbling & 0 & Nightmares & 7 & & \\
\hline Dumb & 3 & Non-caring & 1 & & \\
\hline Embarrass(ed, -ing) & 3 & None caring & 0 & & \\
\hline Empty & 10 & Numscull (Numbskull) & 0 & & \\
\hline Excluded & 0 & Nutcase & 2 & & \\
\hline Feel sorry & 2 & Outcast & 3 & & \\
\hline Freak & 8 & Psycho & 0 & & \\
\hline Fruit cake & 0 & Psychopath & 0 & & \\
\hline Frustrat(ed, -ing) & 1 & Reject & 0 & & \\
\hline Frustration & 0 & Sad & 12 & & \\
\hline
\end{tabular}


Portrayals of Mental Illness and Physical Disability in $21^{\text {st }}$ Century Children's Animation

Appendix G

Total number of appearances of keywords in all animations

\begin{tabular}{|c|c|c|c|c|c|}
\hline Keywords & Total & Keywords & Total & Keywords & Total \\
\hline Abnormal & 0 & Funny & 27 & Scared & 19 \\
\hline Abusive & 3 & Goon & 0 & Scary & 5 \\
\hline Alone & 46 & Halfwit & 0 & Screw loose & 0 \\
\hline Angry & 24 & Hallucinating & 1 & & \\
\hline Antisocial & 0 & Hallucination & 1 & & \\
\hline Bewildered & 0 & Head case & 0 & Overall Total: & 462 \\
\hline Bonkers & 0 & Helpless & 6 & & \\
\hline Breakdown & 0 & Hurting (yourself, someone, anyone) & 6 & & \\
\hline Childish & 0 & Idiot & 9 & & \\
\hline Confused & 17 & III & 0 & & \\
\hline Crazy & 70 & Insane & 1 & & \\
\hline Danger(ous) & 41 & Indecisive & 0 & & \\
\hline Deformed & 0 & Insecure & 0 & & \\
\hline Demanding & 1 & Intimidating & 1 & & \\
\hline Demented & 0 & Irrational & 1 & & \\
\hline Depressed & 2 & Isolated & 2 & & \\
\hline Deranged & 0 & Jumpy & 1 & & \\
\hline Disabled & 0 & Lonely & 2 & & \\
\hline Disarmed & 0 & Loony & 0 & & \\
\hline $\begin{array}{l}\text { Disorientated } \\
\text { (Disoriented) }\end{array}$ & 0 & Loser & 3 & & \\
\hline Distorted & 1 & Lost & 59 & & \\
\hline Distress(ed, -ing) & 0 & Lunatic & 1 & & \\
\hline Disturbed & 1 & Mad & 16 & & \\
\hline Dizzy & 0 & Made fun of & 1 & & \\
\hline Doctors & 1 & Madness & 2 & & \\
\hline Dofuss (Dofus) & 0 & Misunderstood & 3 & & \\
\hline Dopy & 0 & Needing help & 11 & & \\
\hline Down(y) & 3 & Nervous & 6 & & \\
\hline Dribbling & 0 & Nightmares & 9 & & \\
\hline Dumb & 5 & Non-caring & 1 & & \\
\hline $\begin{array}{l}\text { Embarrass(ed, - } \\
\text { ing) }\end{array}$ & 3 & None caring & 0 & & \\
\hline Empty & 14 & Numscull (Numbskull) & 1 & & \\
\hline Excluded & 0 & Nutcase & 3 & & \\
\hline Feel sorry & 2 & Outcast & 3 & & \\
\hline Freak & 12 & Psycho & 0 & & \\
\hline Fruit cake & 0 & Psychopath & 0 & & \\
\hline Frustrat(ed, -ing) & 1 & Reject & 1 & & \\
\hline Frustration & 0 & Sad & 13 & & \\
\hline
\end{tabular}


Portrayals of Mental Illness and Physical Disability in $21^{\text {st }}$ Century Children's Animation Table 1.

71 keywords used during analysis of children's animations.

\begin{tabular}{|c|c|c|}
\hline Keywords & Keywords & Keywords \\
\hline Abnormal & Funny & Scared \\
\hline Abusive & Goon & Scary \\
\hline Alone & Halfwit & Screw loose \\
\hline Angry & Hallucinating & \\
\hline Antisocial & Hallucination & \\
\hline Bewildered & Head case & \\
\hline Bonkers & Helpless & \\
\hline Breakdown & Hurting (yourself, someone, anyone) & \\
\hline Childish & Idiot & \\
\hline Confused & III & \\
\hline Crazy & Insane & \\
\hline Danger(ous) & Indecisive & \\
\hline Deformed & Insecure & \\
\hline Demanding & Intimidating & \\
\hline Demented & Irrational & \\
\hline Depressed & Isolated & \\
\hline Deranged & Jumpy & \\
\hline Disabled & Lonely & \\
\hline Disarmed & Loony & \\
\hline $\begin{array}{l}\text { Disorientated } \\
\text { (Disoriented) }\end{array}$ & Loser & \\
\hline Distorted & Lost & \\
\hline Distress(ed, -ing) & Lunatic & \\
\hline Disturbed & Mad & \\
\hline Dizzy & Made fun of & \\
\hline Doctors & Madness & \\
\hline Dofuss (Dofus) & Misunderstood & \\
\hline Dopy & Needing help & \\
\hline Down(y) & Nervous & \\
\hline Dribbling & Nightmares & \\
\hline Dumb & Non-caring & \\
\hline $\begin{array}{l}\text { Embarrass(ed, - } \\
\text { ing) }\end{array}$ & None caring & \\
\hline Empty & Numscull (Numbskull) & \\
\hline Excluded & Nutcase & \\
\hline Feel sorry & Outcast & \\
\hline Freak & Psycho & \\
\hline Fruit cake & Psychopath & \\
\hline Frustrat(ed, -ing) & Reject & \\
\hline Frustration & Sad & \\
\hline
\end{tabular}


Portrayals of Mental Illness and Physical Disability in $21^{\text {st }}$ Century Children's Animation Table 4.

Methods in which animations portrayed disability.

\begin{tabular}{lll} 
Direct Reference & Metaphor/Thematic & Imagery \\
\hline & Frozen & Frozen \\
\hline Avatar & Avatar & Avatar \\
\hline Dragon & & Dragon \\
\hline Wreck-It Ralph & & Wreck-It Ralph
\end{tabular}

